\title{
Ewa Kosycarz*
}

\section{WPLYW KONDYCJI FINANSOWEJ PODMIOTÓW LECZNICZYCH NA STABILNOŚĆ FINANSOWĄ JEDNOSTEK SAMORZĄDU TERYTORIALNEGO}

\begin{abstract}
Streszczenie
Celem artykułu było przedstawienie skali zadłużenia publicznej służby zdrowia, prób reformowania podmiotów leczniczych niebędących przedsiębiorcami oraz zagrożeń dla stabilności finansowej jednostek samorządu terytorialnego wynikających z działań podmiotów leczniczych podległych JST.

W artykule zostały porównane trzy typy podmiotów leczniczych podległych JST:

- dwa niebędące przedsiębiorcami: jednostki budżetowe i samodzielne publiczne zakłady opieki zdrowotnej,

- spółki kapitałowe.

Analiza porównawcza została skupiona na ryzyku poniesienia przez JST ciężaru zadłużania się podległych podmiotów leczniczych.
\end{abstract}

Słowa kluczowe: system ochrony zdrowia, podmioty lecznicze, SPZOZ, zadłużenie jednostek samorządu terytorialnego

\section{Wprowadzenie}

Temat finansowania służby zdrowia jest niezmiernie istotnym zagadnieniem. Wydatki na ochronę zdrowia stale rosną w większości państw europejskich.

* Ewa Kosycarz, dr, Szkoła Główna Handlowa w Warszawie, Kolegium Zarządzania i Finansów, e-mail: ewa.kosycarz@sgh.waw.pl. 
Wzrost jest nie tylko nominalny, ale powiększa się również ich udział w PKB. Zwiększające się wydatki na ochronę zdrowia mają kilka przyczyn, między innymi: starzejące się społeczeństwo, zwiększone oczekiwania obywateli, rozwój skomplikowanych i kosztownych technik medycznych. Z drugiej strony, źródła finansowania ochrony zdrowia w długim horyzoncie czasowym maleją (ze względu na zmiany struktury demograficznej społeczeństwa).

Problem wydatków na ochronę zdrowia w dużej części dotyczy jednostek samorządu terytorialnego, gdyż należy do ich ustawowo zdefiniowanych zadań. Choć ostatnio pojawiły się pewne wątpliwości wokół zapisów z ustaw o samorządzie gminnym, powiatowym i wojewódzkim - Krakowski Wojewódzki Sąd Administracyjny uznał, że powiaty mogą zgodnie z prawem zrezygnować z prowadzenia szpitali ${ }^{1}$.

Celem niniejszego artykułu jest wskazanie poziomu potencjalnego zadłużenia, jakie w niesprzyjających warunkach może obciążyć jednostki samorządu terytorialnego w związku z zapewnianiem przez JST ochrony zdrowia na swoim terenie. Dodatkowo przeanalizowane są sytuacje, w jakich wspomniane ryzyko może się zrealizować.

\section{Działania oddłużające SPZOZ-y}

Samodzielne publiczne zakłady opieki zdrowotnej (SPZOZ), według ustawy o działalności leczniczej, są podmiotami leczniczymi niebędącymi przedsiębiorcami $^{2}$. W formie SPZOZ-ów mogą działać szpitale, ambulatoria, domy opieki, podstawowa opieka medyczna, itd. SPZOZ-y mogą być prowadzone przez jednostki samorządu terytorialnego, ministrów oraz przez uczelnie medyczne.

W centrum uwagi niniejszego artykułu znajdują się szpitale prowadzone przez JST. Jednak w celu kompleksowego spojrzenia na problem zadłużenia publicznej służby zdrowia, analizie poddane zostały również dane o zadłużeniu całej grupy podmiotów sklasyfikowanych jako SPZOZ-y.

Wielokrotnie w historii funkcjonowania polskiego systemu ochrony zdrowia zadłużenie podmiotów leczniczych było tak ogromne, że władze wprowadzały pewne zestawy instrumentów finansowych, które miały w radykalny sposób poprawić sytuację.

1 K. Nowosielska, Samorzady nie musza prowadzić szpitali, „Rzeczpospolita”, e-wydanie, http://beta.rp.pl/artykul/1190671-Samorzady-nie-musza-prowadzic-szpitali.html (2.04.2015).

2 Podmiotami leczniczymi niebędącymi przedsiębiorcami są jeszcze, zgodnie z ustawą o działalności leczniczej z 2011 r., jednostki budżetowe. 
W 1999 roku zadłużenie jednostek dostarczających świadczenia zdrowotne wyniosło ok. 8,5 mld zł. W tym czasie świadczeniodawcami były głównie jednostki budżetowe, które pomimo obowiązywania dyscypliny budżetowej zadłużały się w szybkim tempie. Aby rozwiązać ten problem, zostały wyemitowane obligacje skarbowe na pokrycie długu sektora opieki zdrowotnej i budżet państwa pokrył to ogromne zadłużenie. Została w tym okresie przeprowadzona reforma, zmieniająca formę prawną świadczeniodawców (zostały przekształcone w zakłady opieki zdrowotnej), co miało usprawnić ich działanie. Zostały również wprowadzone kasy chorych. Sytuacja jednak nie poprawiła się na tyle znacząco, aby państwo nie musiało podejmować kolejnych działań3

I tak 15 kwietnia 2005 roku Sejm uchwalił ustawę o pomocy publicznej i restrukturyzacji publicznych zakładów opieki zdrowotnej ${ }^{4}$. Zgodnie z ustawą zobowiązania SPZOZ-ów miały zostać zrestrukturyzowane. W tym celu było planowane umorzenie części zobowiązań. Zobowiązania wobec dostawców towarów i usług, jak również wobec pracowników, miały mieć wynegocjowane porozumienia umożliwiające ich spłatę. SPZOZ-y restrukturyzując zadłużenie, mogły korzystać z pożyczek budżetu państwa, dotacji organu tworzącego, kredytów bankowych oraz z możliwości emisji papierów wartościowych (obligacji).

Autorzy raportu Centralne finansowanie ochrony zdrowia $i$ edukacji $w$ Polsce wyliczyli w oparciu o dane Ministerstwa Finansów i Ministerstwa Zdrowia, że wprowadzona w życie ustawa o pomocy publicznej i restrukturyzacji publicznych zakładów opieki zdrowotnej nie odniosła sukcesu. Nie tylko kosztowała budżet państwa i budżety jednostek samorządu terytorialnego ogromne pieniądze, ale dodatkowo specjalnie nie polepszyła sytuacji SPZOZ-ów. Zmiana ich sytuacji finansowej polegała na tym, że zmniejszyły się zobowiązania wymagalne, ale całkowite zobowiązania wzrosły. W tabeli 1 ukazano, jak przebiegał proces restrukturyzacji w tamtym okresie. Wyraźnie widać, że nowe zobowiązania SPZOZ-ów były większe niż uzyskana pomoc. W okresie procesu restrukturyzacji spadła o ponad 2 mld zł kwota zobowiązań wymagalnych. Jednak nie można tego uznać za duży sukces, zważywszy, że osiągnięto to m.in. zaciągnięciem pożyczek i kredytów na ponad 1 mld zł, pożyczką z budżetu państwa na ponad 1,6 mld zł i 99 mln z emisji obligacji - czyli rolowaniem długu, przy jednoczesnym pojawieniu się nowych zobowiązań niewymagalnych, przekraczających

\footnotetext{
3 Krajowy indeks sprawności ochrony zdrowia 2014, Pierwsza edycja, styczeń 2014, PWC, s. 50.

${ }^{4}$ Malinowska-Misiąg E., Misiąg W., Tomalak M., Centralne Finansowanie Ochrony Zdrowia i Edukacji w Polsce, Instytut Badań nad Gospodarką Rynkową, Warszawa 2008, s. 81.
} 
swą kwotą wszystkie umorzenia i dotacje. Taka sytuacja oznaczała, że w krótkim horyzoncie czasowym istnieje ryzyko, że sytuacja SPZOZ-ów ulegnie pogorszeniu. Każdy rolowany dług w końcu trzeba spłacić. Jak pokazują dane empiryczne z kolejnych lat (patrz rys. 1), poziom zobowiązań ogółem pozostał bardzo wysoki, jednak zobowiązania wymagalne udało się utrzymać na poziomie po restrukturyzacji z lat 2005-2006. Poziom zobowiązań ogółem nie jest problemem dla stabilności finansowej, jeśli podmioty lecznicze nie mają zobowiązań wymagalnych.

Kolejny istotny krok w ograniczaniu zadłużenia SPZOZ-ów podjęto 27 kwietnia 2009 roku. Rada Ministrów przyjęła tego dnia uchwałę o uruchomieniu programu wieloletniego pod nazwą Wsparcie jednostek samorzadu terytorialnego $w$ działaniach stabilizujacych system ochrony zdrowia ${ }^{5}$.

Tabela 1

Proces restrukturyzacji zobowiązań ${ }^{6}$ w latach 2005-2006 (mln zł)

\begin{tabular}{|l|r|r|}
\hline \multicolumn{1}{|c|}{ Treść } & \multicolumn{2}{c|}{ Zobowiązania } \\
\cline { 2 - 3 } & ogółem & wymagane \\
\hline Zobowiązania na koniec 2004 roku & 6172 & 5684 \\
\hline Umorzenie zobowiązań publicznoprawnych & -543 & -543 \\
\hline Dotacje z JST na spłatę zobowiązań & -239 & -239 \\
\hline Umorzenie zobowiązań cywilnoprawnych w drodze porozumień & -222 & -222 \\
\hline Dług przejęty przez organy założycielskie & -213 & -213 \\
\hline Nowe zobowiązania - spłaty z własnych środków & +1830 & +1927 \\
\hline Pożyczki i kredyty zaciągnięte i wykorzystane na spłatę długu & & -1077 \\
\hline Emisja obligacji wykorzystanych na spłatę długu & & -99 \\
\hline Pożyczka z budżetu państwa zaciągnięta i wykorzystana na spłatę długu & & -1614 \\
\hline Zobowiązania na koniec 2006 roku & 6785 & 3604 \\
\hline
\end{tabular}

Źródło: E. Malinowska-Misiąg, W. Misiąg, M. Tomalak, Centralne finansowanie ochrony zdrowia i edukacji w Polsce, Instytut Badań nad Gospodarką Rynkową, Warszawa 2008, s. 82.

Program wieloletni Wsparcie jednostek samorzadu terytorialnego w działaniach stabilizujacych system ochrony zdrowia miał na celu zmniejszenie zadłużenia SPZOZ-ów poprzez przekształcanie ich w spółki kapitałowe. Uznano, że w takiej formie jednostki te będą znacznie racjonalniej funkcjonowały. Taką decyzję podjęto po przeanalizowaniu 71 przykładów szpitali (głównie powiatowych)

5 www2.mz.gov.pl/wwwfiles/ma_struktura/docs/uchwala_wsparcie_07052009.pdf.

${ }^{6}$ Dane według sprawozdań $\mathrm{Rb}-\mathrm{Z}$ - nie uwzględniają odsetek od zobowiązań oraz zobowiązań niewymagalnych z tytułu dostaw i usług oraz wobec pracowników. 
przekształconych w latach 1999-2008. Do roku 2008 obserwuje się wyraźne ograniczenie zobowiązań wymagalnych SPZOZ tworzonych przez JST (rys. 2).

Przekształcenia miały odbywać się pod warunkiem, że samorządy obejmują 100\% udziału w spółkach. W zamian za przekształcenia (po wprowadzeniu programu lub przed) jednostki samorządu mogły liczyć na dotację finansującą przejmowane przez JST zobowiązania po likwidowanych SPZOZ-ach. Planowano, że program będzie obowiązywał w latach 2009-2011 i przeznaczono na jego realizację $1381 \mathrm{mln}$ zł z budżetu państwa. Prognozowano, że przeprowadzane przekształcenia spowodują zmniejszenie poziomu zobowiązań SPZOZ-ów o 2,9 mld zt? .

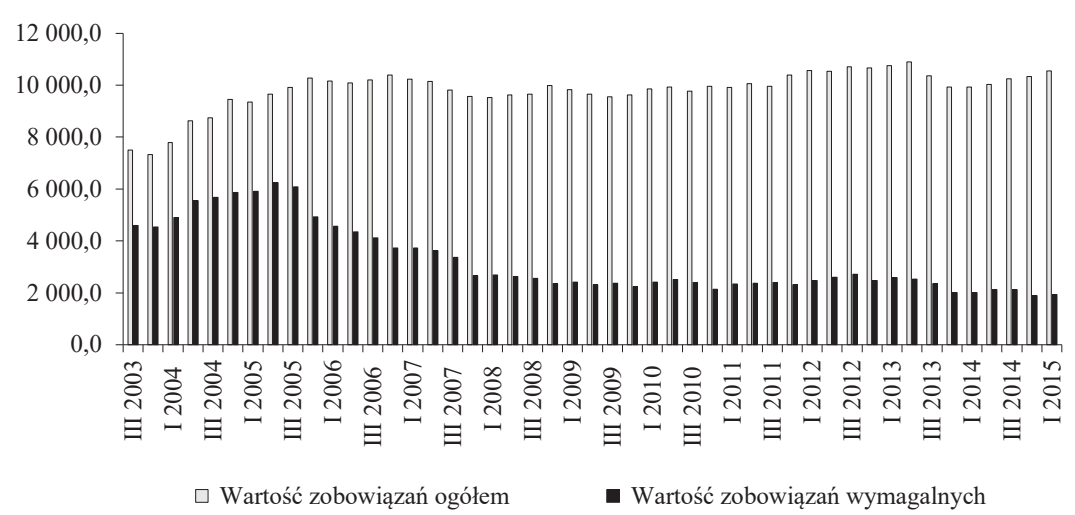

Rysunek 1. Wartość zobowiązań ogółem i wszystkich wymagalnych samodzielnych publicznych zakładów opieki zdrowotnej w okresie III kw. 2003 - I kw. 2015 (mln zł)

Źródło: opracowanie własne na podstawie danych Ministerstwa Zdrowia, www.mz.gov.pl/system -ochrony-zdrowia/organizacja-ochrony-zdrowia/zadluzenie-spzoz (sierpień 2015).

Rok 2011 to czas kolejnych przemian w systemie ochrony zdrowia. Przestaje obowiązywać ustawa o zakładach opieki zdrowotnej. W jej miejsce wchodzi ustawa z 15 kwietnia o działalności leczniczej. Nowe przepisy wręcz nakazują likwidację lub przekształcenia dla SPZOZ-ów, jeśli zaistnieją pewne okoliczności.

7 Uchwała nr 58/2009 Rady Ministrów z dnia 27 kwietnia 2009 r. w sprawie ustanowienia programu wieloletniego pod nazwą ,Wsparcie jednostek samorządu terytorialnego w działaniach stabilizujących system ochrony zdrowia", www2.mz.gov.pl/wwwfiles/ma_struktura/docs/uchwala_wsparcie_07052009.pdf. 
Zgodnie z art. 59 ustawy o działalności leczniczej:

„1. Samodzielny publiczny zakład opieki zdrowotnej pokrywa we własnym zakresie ujemny wynik finansowy.

2. Podmiot tworzący samodzielny publiczny zakład opieki zdrowotnej może, w terminie 3 miesięcy od upływu terminu zatwierdzenia sprawozdania finansowego samodzielnego publicznego zakładu opieki zdrowotnej, pokryć ujemny wynik finansowy za rok obrotowy tego zakładu, jeżeli wynik ten, po dodaniu kosztów amortyzacji, ma wartość ujemną - do wysokości tej wartości.

3. Ujemny wynik finansowy i koszty amortyzacji, o których mowa w ust. 2, dotyczą roku obrotowego objętego sprawozdaniem finansowym.

4. W przypadku niepokrycia ujemnego wyniku finansowego w sposób określony w ust. 2 podmiot tworzący w terminie 12 miesięcy od upływu terminu określonego w ust. 2 wydaje rozporządzenie, zarządzenie albo podejmuje uchwałę o zmianie formy organizacyjno-prawnej albo o likwidacji samodzielnego publicznego zakładu opieki zdrowotnej”.

Ust 1. wskazuje, że SPZOZ-y powinny być samofinansujące się. Źródła dochodów opisane są w art. 44 i 55 ustawy o działalności leczniczej.

Ust 4. daje dwie możliwości SPZOZ, jeśli strata SPZOZ-u nie zostanie pokryta przez organ tworzący: likwidację lub przekształcenie w spółkę prawa handlowego.

Przekształceniom towarzyszyły dotacje na pokrycie zobowiązań podmiotów przekształcanych. Dotacje były bardzo zróżnicowane pod względem wartości. Całkowita kwota dotacji udzielona w latach 2012-2013 na ten cel to 271246 609,48 zł, przy czym 101970 533,12 zł (czyli ponad 1/3) otrzymał Urząd Marszałkowski Województwa Lubuskiego na przekształcenie Samodzielnego Publicznego Szpitala Wojewódzkiego w Gorzowie Wielkopolskim.

Dotychczasowe zmiany $\mathrm{w}$ przepisach spowodowały, że w okresie od 1.01.1999 do 5.09.2013 roku zostały przekształcone 152 szpitale, działające uprzednio w formie SPZOZ. Z tego 138 przekształcono w spółkę z ograniczoną odpowiedzialnością, 11 w spółkę akcyjną i po jednym: w spółkę cywilną, spółkę jawną, a jeden prowadzony jest przez osobę fizyczną (w ramach działalności gospodarczej). Najwięcej szpitali przekształciły powiaty (93). Pozostałe jednostki samorządu terytorialnego przekształciły odpowiednio: samorządy wojewódzkie -30 , miasta -22 , gminy -6 szpitali. Tylko jeden szpital został przekształcony przez ministra zdrowia ${ }^{8}$.

${ }_{8}$ M. Wielgolaski, D. Woźniak, Spótki lecznicze, w: Spótki jednostek samorzadu terytorialnego, red. A. Zołotar, Wydawnictwo C.H. Beck 2014, s. 401. 
Wpływ kondycji finansowej podmiotów leczniczych na stabilność finansowa... 203

Tabela 2

Liczba szpitali przekształconych w spółki kapitałowe w latach 2001-2013

\begin{tabular}{|c|c|c|c|c|c|c|c|c|c|c|c|c|c|}
\hline Rok & 홍 & ঠి & ڤి & ষ্ণ & 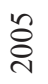 & ঃ̊ & 홍 & $\stackrel{\infty}{\stackrel{8}{\circ}}$ & \&े & $\stackrel{\circ}{\stackrel{0}{\circ}}$ & $\overrightarrow{\bar{\sim}}$ & $\frac{\sim}{\stackrel{N}{d}}$ & $\stackrel{n}{\stackrel{2}{\sim}}$ \\
\hline $\begin{array}{l}\text { Liczba szpitali } \\
\text { przekształco- } \\
\text { nych w spółki } \\
\text { kapitałowe }\end{array}$ & 6 & 8 & 5 & 14 & 5 & 3 & 9 & 19 & 21 & 22 & 12 & 16 & 27 \\
\hline
\end{tabular}

Źródło: Sytuacja finansowa szpitali w Polsce, edycja 2014, Raport firmy Magellan, www.magellansa.pl/Portals/1/Files/Raporty\%20rynkowe/Raport_Sytuacja\%20finansowa\%20szpitali\%20w\%20Polsce.pdf.

Przekształcenia SPZOZ w spółki kapitałowe nie dotyczyły tylko szpitali. W roku 2008, jak podaje Ministerstwo Zdrowia na swoich internetowych stronach, na 212 przekształconych jednostek, dla których organem tworzącym były jednostki samorządu terytorialnego, było: 59 szpitali, 118 zakładów lecznictwa ambulatoryjnego, 35 oddziałów szpitalnych ${ }^{9}$.

Dane podawane przez Ministerstwo Zdrowia wskazują, że to głównie jednostki samorządu terytorialnego decydowały się na przekształcenia szpitali. Wynika to z sytuacji finansowej jednostek, jak również z faktu, że to jednostki samorządu terytorialnego są najliczniejszą grupą organów tworzących.

Zmiany w poziomie zobowiązań wymagalnych w SPZOZ-ach, w których organem tworzącym jest jednostka samorządowa, w latach 2002-2015 (rys. 2) były wynikiem rządowych programów pomocowych opisanych powyżej, zmianą w podejściu do zarządzania szpitalami i całym systemem ochrony zdrowia oraz zmniejszającą się liczbą SPZOZ-ów.

Zmniejszająca się liczba SPZOZ-ów powinna prowadzić do ograniczenia całkowitego poziomu zadłużenia tej grupy podmiotów leczniczych. I tak też się działo od 2004 do 2008 roku. Od 2008 do 2012 roku zanotowano wzrost zobowiązań wymagalnych z tytułu dostaw i usług, przy w miarę stałym poziomie zobowiązań wymagalnych. Oznacza to, że zmniejszyły się w tym okresie zobowiązania publicznoprawne. Przy ciągłym spadku liczby SPZOZ-ów pozostawanie na tym samym poziomie zobowiązań wymagalnych oznacza zwiększenie się zobowiązań wymagalnych przypadających na jeden SPZOZ. Oznaczałoby to, że

9 W Polscew 2008 roku funkcjonowały 2704 publiczne zakłady opieki zdrowotnej, w tym: 712 zakładówstacjonarnych, 1992zakładyambulatoryjnejopiekizdrowotnej.DanezestronMinisterstwa Zdrowia, www2.mz.gov.pl/wwwmz/index?mr $=$ b3\&ms $=0 \& m l=p l \& m i=4 \& m x=0 \& m t=\& m y=180$ $\& m a=010479$. 
sytuacja finansowa niektórych podmiotów leczniczych, które nie zdecydowały się na zmianę formy prawnej, pogorszyła się.

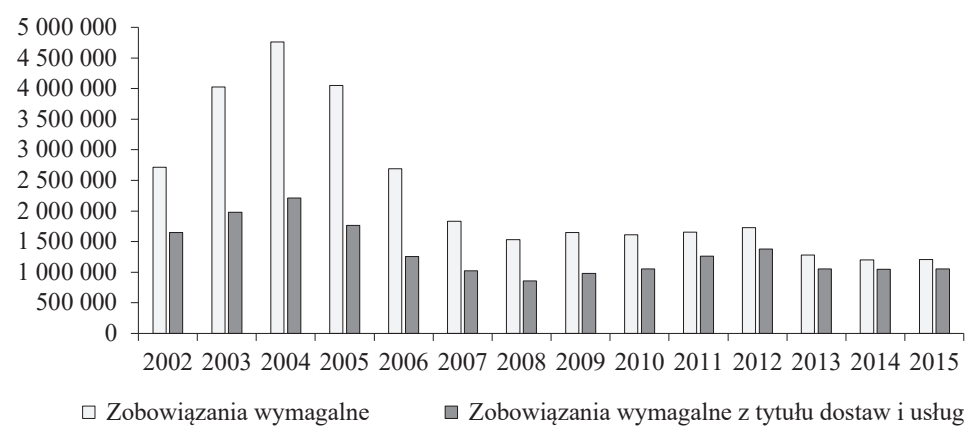

Rysunek 2. Zobowiązania wymagalne SP ZOZ utworzonych przez jednostki samorządu terytorialnego w latach 2002-2015 (zł)

Źródło: opracowanie własne na podstawie danych Ministerstwa Zdrowia, www.mz.gov.pl/system -ochrony-zdrowia/organizacja-ochrony-zdrowia/zadluzenie-spzoz, (sierpień 2015).

Zwiększanie zobowiązań z tytułu dostaw i usług jest nie tylko niebezpieczne, jeśli chodzi o stabilność pracy samych podmiotów leczniczych, ale również oddziałuje na płynność przedsiębiorstw zaopatrujących i współpracujących z podmiotami leczniczymi.

Podobny charakter zmian obserwuje się w poziomie zadłużenia wszystkich SPZOZ-ów.

\section{Wpływ formy prowadzenia działalności leczniczej przez władze samorządowe na zadłużenie JST i sektora finansów publicznych}

Ustawa o działalności leczniczej z 2011 roku wymienia następujące formy prawne, w których mogą działać podmioty lecznicze prowadzone przez jednostki samorządu terytorialnego:

- spółkę kapitałową,

- jednostkę budżetową,

- samodzielny publiczny zakład opieki zdrowotnej.

Przy czym art. 6 ust. 2 mówi, że jednostka samorządu terytorialnego może utworzyć i prowadzić podmiot leczniczy w formie: 
- spółki kapitałowej,

- jednostki budżetowej ${ }^{10}$.

Oznacza, to, że nie można już tworzyć nowych podmiotów leczniczych $\mathrm{w}$ formie SPZOZ. Jednak dotychczas utworzone mogą w takiej formie nadal funkcjonować. Musiały tylko dostosować swoje działanie do ustawy o działalności leczniczej.

Podmioty lecznicze funkcjonujące w postaci jednostki budżetowej należą do rzadkości.

Zgodnie z art. 11 ust. 1 ustawy o finansach publicznych z 2009 roku ,,jednostkami budżetowymi są jednostki organizacyjne sektora finansów publicznych nieposiadające osobowości prawnej, które pokrywają swoje wydatki bezpośrednio z budżetu, a pobrane dochody odprowadzają na rachunek odpowiednio dochodów budżetu państwa albo budżetu jednostki samorządu terytorialnego". Stąd też deficyt powstający w takiej jednostce w całkowitej wielkości obciążałby wynik finansowy jednostki samorządu terytorialnego. I automatycznie wliczany byłby do deficytu sektora finansów publicznych.

Dług SPZOZ-ów nie jest wliczany do długu sektora samorządowego, ale ze względu na to, że SPZOZ-y są jednostkami sektora finansów publicznych (art. 9 ufp), wchodzi on w skład państwowego długu publicznego.

Długi spółek kapitałowych, których właścicielami są jednostki samorządu terytorialnego, nie są wliczane ani do państwowego długu publicznego, ani do długu jednostek samorządu terytorialnego.

Mogłoby się wydawać, że z takiego punktu widzenia obie formy prawne podmiotów leczniczych są bezpieczne dla stabilności finansowej jednostek samorządu terytorialnego.

Jednak jeśli podmiot leczniczy działający w postaci SPZOZ ma problemy finansowe (z samodzielnym pokryciem ujemnego wyniku i/lub wysokie zadłużenie), to zgodnie z cytowanym wcześniej art. 59 ustawy o działalności leczniczej organ tworzący musi pokryć stratę lub zlikwidować albo przekształcić SPZOZ w spółkę kapitałową. Każdy z wymienionych wariantów oznacza dla jednostki samorządu terytorialnego przejęcie na siebie ciężaru finansowego z podmiotu leczniczego.

W przypadku pokrycia straty jest to wydatek związany z wielkością straty. Niestety może się on pojawiać cyklicznie. W dwóch pozostałych rozwiązaniach koszty mogą być znacznie większe, choć są jednokrotne. 
Art. 61 ustawy o działalności leczniczej mówi, że przy likwidacji SPZOZ wszystkie zobowiązania, należności i mienie przechodzą na rzecz podmiotu tworzącego. Zakładając, że likwidowane podmioty posiadają wysoki stan zobowiązań, należy przypuszczać, że nie jest to pożądane rozwiązanie dla organu tworzącego. Dodatkowo, w większości przypadków, organ tworzący powinien wypełniać zobowiązania art. 68 Konstytucji RP, w którym zapisano, że państwo gwarantuje dostęp do ochrony zdrowia swoim obywatelom. W związku z tym bardziej prawdopodobne będzie przekształcenie nierentownego SPZOZ w spółkę kapitałową. Szczególnie że w takich przypadkach organ tworzący mógł dotychczas liczyć na pomoc budżetu państwa w spłacie części zobowiązań ${ }^{11}$.

Innym działaniem wspomagającym samorządy w przekształceniach SPZOZ jest zapis z art. 36 ustawy z dnia 7 grudnia 2012 r. o zmianie niektórych ustaw w związku z realizacją ustawy budżetowej ${ }^{12}$. Art. 36 wprowadza wyłączenie zobowiązań JST wynikających z przekształcenia SPZOZ ze stosowania art. 242 i 243 ustawy o finansach publicznych (które ograniczają jednostki samorządu terytorialnego w przygotowywaniu budżetu na kolejny rok [zrównoważenie budżetu w części bieżącej i rygory poziomu zadłużenia]) $)^{13}$.

Spółka powstała w procesie przekształcenia należy do organu tworzącego SPZOZ. Bardzo istotne dla procesu przekształcania SPZOZ-u w spółkę kapitałową są art. 70, 71, 72 ustawy o działalności leczniczej:

„Art. 70. Podmiot tworzący, na podstawie przychodów ze sprawozdania finansowego za ostatni rok obrotowy oraz danych o zobowiązaniach i inwestycjach krótkoterminowych według stanu na dzień poprzedzający dzień złożenia wniosku o wpisanie spółki kapitałowej do rejestru przedsiębiorców, ustala wskaźnik zadłużenia samodzielnego publicznego zakładu opieki zdrowotnej.

Art. 71. Wskaźnik zadłużenia ustala się jako relację sumy zobowiązań długoterminowych i krótkoterminowych, pomniejszonych o inwestycje krótkoterminowe samodzielnego publicznego zakładu opieki zdrowotnej do sumy jego przychodów.

Art. 72.1. Jeżeli wartość wskaźnika zadłużenia ustalona zgodnie z art. 70 i 71 wynosi:

${ }^{11}$ Umorzenie zobowiązań publicznoprawnych lub dotacja celowa na pozostałe zobowiązania.

12 DzU z 2012 r., poz. 1456.

13 Szerzej w: D. Woźniak, Przekształcenia w ochronie zdrowia i ich wplyw na zadtużenie JST, w: Zadtużenie jednostek samorzadu terytorialnego, Wyzwania w obliczu nowej perspektywy finansowej UE, red. P. Walczak, Wydawnictwo C.H. Beck, Warszawa 2014, s. 303-304. 
1) powyżej 0,5 - podmiot tworzący, przed dniem przekształcenia, przejmuje zobowiązania samodzielnego publicznego zakładu opieki zdrowotnej o takiej wartości, aby wskaźnik zadłużenia wyniósł nie więcej niż 0,5 ;

2) 0,5 lub mniej - podmiot tworzący może, przed dniem przekształcenia, przejąć zobowiązania samodzielnego publicznego zakładu opieki zdrowotnej.

2. Przejęciu w pierwszej kolejności podlegają zobowiązania wymagalne najdawniej obejmujące kwotę glówną wraz z odsetkami”.

Wspomniane wyżej zapisy są niebezpieczne dla finansów organu tworzącego, szczególnie jednostki samorządu terytorialnego, którego budżet roczny jest niejednokrotnie mniejszy niż zadłużenie podległego SPZOZ-u.

Z punktu widzenia pacjenta istnieje ryzyko, że w przyszłości jednostki samorządu terytorialnego mogą pozbywać się większościowego udziału w spółce kapitałowej i nowy większościowy udziałowiec będzie się kierował wyłącznie zyskiem, a nie zapisami Konstytucji. Jednak jeśli świadczenia medyczne będą dobrze wycenione przez NFZ, takie ryzyko jest minimalizowane.

Ustawodawca wprowadzając zapisy umożliwiające przekształcenia szpitali oraz zmuszające do nich w skrajnych przypadkach, kierował się efektywnością i skutecznością zarządzania podmiotem leczniczym w obu formach: SPZOZ i spółki kapitałowej.

Spółki kapitałowe powstałe w wyniku przekształcenia SPZOZ-u działają w oparciu o kodeks spółek handlowych i w pewnym stopniu w oparciu o ustawę o działalności leczniczej ${ }^{14}$. Nie podlegają przepisom dotyczącym gospodarki komunalnej.

JST jako właściciel spółki może ją wspierać finansowo w formie zwrotnej lub bezzwrotnej. Jedną z form wsparcia jest podwyższenie kapitału zakładowego $^{15}$.

Główne różnice w zarządzaniu i funkcjonowaniu SPZOZ-ów i spółek kapitałowych (działających jako podmioty lecznicze) należących do jednostek samorządu terytorialnego znajdują się w obszarach:

- możliwości świadczenia usług komercyjnych (przewagę mają spółki kapitałowe),

- zarządzania i nadzoru (złożone aspekty),

${ }^{14}$ Szerzej M. Wielgolaski, D. Woźniak, Spótki lecznicze, s. 395.

15 Szerzej M. Bitner, Spótki prawa handlowego - przeniesienie zadtużenia poza JST, w: Zadlużenie jednostek samorzadu terytorialnego. Wyzwania w obliczu nowej perspektywy finansowej UE, red. P. Walczak, Wydawnictwo C.H. Beck, Warszawa 2014, s. 256 
- w płaceniu podatków (przewagę mają SPZOZ-y) $)^{16}$,

- zarządzania płynnością finansową (przewagę mają spółki kapitałowe),

- bycia w stanie upadłości.

Ostatni z wymienionych obszarów może być różnie oceniany ze względu na stabilność finansów samorządu terytorialnego. W przypadku SPZOZ-ów nie ma możliwości upadłości. Stąd też niejednokrotnie można spotkać się z opinią, że skutkowało to nieprawidłowym zarządzaniem finansami w SPZOZ-ach i narastaniem ich zadłużenia. $Z$ drugiej strony, gwarantowało dostawę usług medycznych (jeśli długi nie sparaliżowały działalności szpitala). W skrajnych przypadkach SPZOZ-y dostawały pomoc finansową od państwa. Brak możliwości upadłości powoduje jednak niemożność skorzystania z prawa upadłościowego i w ten sposób ratowania sytuacji finansowej szpitala poprzez restrukturyzację zadłużenia (co nie oznacza likwidacji podmiotu, tylko restrukturyzację). Możliwość upadłości wprowadza jednak ryzyko, że zabraknie świadczeniodawcy usług medycznych lub usługi zostaną ograniczone do tych rentownych.

\section{Podsumowanie}

Problem zadłużenia podmiotów leczniczych prowadzonych przez jednostki samorządu terytorialnego jest bardzo złożony i jest jednym z elementów skomplikowanego systemu finansowania służby zdrowia w Polsce. Jego wyjątkowość $\mathrm{i}$ istotność wynika z:

- niskich nakładów na ochronę zdrowia ${ }^{17}$,

- wrażliwości społecznej na dostępność i jakość usług medycznych (szczególnie medycyny naprawczej),

- systemu podziału środków publicznych na ochronę zdrowia,

- konkurencyjności różnych form prawnych podmiotów leczniczych.

Pomimo wysiłków kolejnych rządów sytuacja finansowa podmiotów leczniczych niebędących przedsiębiorcami nie ulega w skali kraju poprawie (na co wskazują dane z rys. 1 i 2). Oczywiście są szpitale, zarówno działające jako

16 Szerzej w piśmie Ministerstwa Zdrowia do Marszałka Senatu Bogdana Borusewicza z dnia 21.01.2014 r., www.senat.gov.pl/gfx/senat/userfiles/_public/k8/dokumenty/stenogram/oswiadczenia/arlukowicz/4605oa.pdf.

17 W kontekście innych państw UE. 
SPZOZ-y, jak i jako spółki kapitałowe, które sobie radzą bardzo dobrze, najczęściej znajdując niszę w wysoko wycenianych usługach medycznych ${ }^{18}$.

Jak pokazuje raport NIK-u ${ }^{19}$, zmiana SPZOZ w spółkę kapitałową (z udziałami organu tworzącego poprzednio SPZOZ) nie musi oznaczać zmiany w sposobie zarządzania szpitalem. Niestety odnosi się to również do złych praktyk.

To, co warto zaznaczyć, kontrola NIK wykazała, że podmioty lecznicze działające w formie spółek kapitałowych ze 100\% lub większościowym udziałem jednostek samorządu terytorialnego (kontrolowane przez NIK) nie ograniczyły liczby i zakresu wykonywanych świadczeń zdrowotnych finansowanych ze środków publicznych.

W najbliższej przyszłości stoi przed szpitalami kolejne wyzwanie: dostosowanie infrastruktury szpitalnej do norm $\mathrm{UE}^{20}$. Jest to związane z dużymi wydatkami inwestycyjnymi. Jednym z rozwiązań, które można rozważać w takim układzie, jest partnerstwo publiczno-prywatne. Taką drogę wyjścia wybrał np. powiat prowadzący szpital w Żywcu.

Szanse i ryzyko, jakie niesie ze sobą przekształcanie SPZOZ-ów w spółki kapitałowe, jest bardzo rozległym i złożonym zagadnieniem. W części dotyczy to stabilności finansowej jednostek samorządu terytorialnego, ale ma również wpływ na wiele innych obszarów związanych z systemem ochrony zdrowia w Polsce.

\section{Literatura}

Informacja o wynikach kontroli. Działalność szpitali samorządowych przekształconych w spółki kapitałowe, NIK, Warszawa 2.03.2015.

Krajowy indeks sprawności ochrony zdrowia 2014, Pierwsza edycja, PWC, styczeń 2014.

Malinowska-Misiąg E., Misiąg W., Tomalak M., Centralne finansowanie ochrony zdrowia i edukacji w Polsce, Instytut Badań nad Gospodarką Rynkową, Warszawa 2008.

Nowosielska K., Samorząy nie musza prowadzić szpitali, „Rzeczpospolita”, e-wydanie, http://beta.rp.pl/artykul/1190671-Samorzady-nie-musza-prowadzic-szpitali.html, (2.04.2015).

Pismo Ministra Zdrowia do Marszałka Senatu z dnia 21.01.2014 r.

${ }^{18} \mathrm{~W}$ ten sposób poradziły sobie niektóre szpitale powiatowe, które utworzyły zespoły i oddziały świadczące wysokospecjalistyczne usługi medyczne.

19 Informacja o wynikach kontroli. Działalność szpitali samorządowych przekształconych w spółki kapitałowe, NIK, Warszawa 2.03.2015.

${ }^{20}$ Rozporządzenie Ministra Zdrowia z dnia 26 czerwca 2012 r. w sprawie szczegółowych wymagań, jakim powinny odpowiadać pomieszczenia i urządzenia podmiotu wykonującego działalność leczniczą, DzU, poz. 739. 
Spółki jednostek samorządu terytorialnego, red. A. Zołotar, Wydawnictwo C.H. Beck, Warszawa 2014.

Sytuacja finansowa szpitali w Polsce, Raport firmy Magellan, 2014.

Zadtużenie jednostek samorzadu terytorialnego. Wyzwania w obliczu nowej perspektywy finansowej UE, red. P. Walczak, Wydawnictwo C.H. Beck, Warszawa 2014.

\title{
Źródla internetowe
}

www.magellansa.pl.

www.mz.gov.pl.

www.senat.gov.pl.

www2.mz.gov.pl.

www.portalzdrowie.pl.

\section{Ustawy}

Ustawa z dnia 27 sierpnia 2004 r. o świadczeniach opieki zdrowotnej finansowanych ze środków publicznych, DzU z 2004 r., nr 210, poz. 2135.

Ustawa o finansach publicznych z dnia 27 sierpnia 2009 r., DzU z 2009 r., nr 157, poz. 1240 .

Ustawa o działalności leczniczej z dnia 15 kwietnia 2011 r., DzU z 2011 r., nr 112, poz. 654.

\section{IMPACT OF FINANCIAL SITUATION OF HEALTHCARE ENTITIES ON FINANCIAL STABILITY OF LOCAL GOVERNMENT UNITS}

\begin{abstract}
Summary
The purpose of this paper is to present the scale of debt of public health services, various attempts to reform healthcare entities that are not medical enterprises (budgetary units, independent public healthcare establishments) as well as threats to the financial stability of local government units that are a consequence of activities of dependent healthcare entities. The paper compares 3 types of healthcare entities that are dependent on local governments: entities that are not enterprises (budgetary units and independent public healthcare establishments) as well as limited companies. Comparative analysis was focused on risks to local government units from taking over debts of dependent medical entities.
\end{abstract}

Keywords: health care system, medical entities, independent public healthcare establishments, the debt of local government units 